\title{
Association between Fruit Characteristics and Postharvest Stability of Different Pumpkin (Cucurbita) Species
}

\author{
Nulu Nansikombi ${ }^{1}$, John Herbert Muyonga ${ }^{1} \&$ Yusuf Byenkya Byaruhanga ${ }^{1}$ \\ ${ }^{1}$ School of Food Technology, Nutrition and Bio-engineering, Makerere University, Uganda \\ Correspondence: Yusuf B. Byaruhanga, School of Food Technology, Nutrition and Bio-engineering, Makerere \\ University P. O Box 7062 Kampala, Uganda. Tel: 256-772-445-113. E-mail: ybbyaru@ gmail.com
}

Received: May 29, 2019

doi:10.5539/jfr.v8n4p131
Accepted: June 13, 2019 Online Published: July 18, 2019

URL: https://doi.org/10.5539/jfr.v8n4p131

\begin{abstract}
This study aimed at understanding peel and flesh characteristics of Cucurbita maxima Duchesne subsp maxima, Cucurbita pepo L var. fastigata and Cucurbita moschata Decne pumpkin varieties and how the fruit characteristics relate to its postharvest stability. Mature fruits were stored at ambient conditions $\left(28^{\circ} \mathrm{C}\right.$ and $78 \%$ Relative humidity) for eight months. Cell microscopic structure, intercellular space size, sugars, starch, cellulose, hemicellulose, lignin, degree of esterification of pectin, polygalacturonase activity, and cumulative moisture lost were determined monthly. Sucrose, starch, cellulose and hemicellulose content and degree of esterification of pectin of different varieties decreased with storage. Glucose and fructose content increased to a maximum and then reduced. Polygalacturonase activity and lignin generally increased with storage time. Size of intercellular spaces, and cumulative moisture lost from both flesh and peel increased with storage. Sucrose breakdown was key during 0 to 3 months, while moisture loss was important at 4 months of storage. Polygalacturonase activity became paramount from $7^{\text {th }}$ month of storage. Postharvest stability of pumpkins is determined by an interplay of factors. The deterministic factor changes with time. Pumpkin varieties with more lignified peel had lower rates of sucrose breakdown and moisture loss and tended to be more stable postharvest. Varieties with low level of hemicellulose had their cell walls degrade early, while deterioration of pumpkins with highly esterified pectin and closely packed cells was delayed.
\end{abstract}

Keywords: pumpkin varieties, fruit, stability determinants, factor analysis

\section{Introduction}

Pumpkin (Cucurbita spp) is reported to be agronomically a less demanding and weather tolerant crop. Besides, FAO (1994) reported existence of diverse pumpkins species. Although there are five domesticated species, three species namely Cucurbita maxima, Cucurbita pepo and Cucurbita moschata are considered of economic importance. Yet still, the three species of economic importance have many varieties under them.

FAO, (1994) classified pumpkin as a neglected crop and describes neglected crops as those either; associated with low income generation, strongly linked to their places of origin, locally produced or wild species or with their facts poorly documented for example their distribution, biology, cultivation, uses among others. Total crop land for Africa was estimated at 1.4billion ha in 2016. As of 2017, pumpkins, squash and gourds production covered only $344,755 \mathrm{ha}$, corresponding to $0.02 \%$ (FAO, 2019).

Just like any other agricultural product, pumpkins are subject to changes in quality postharvest. For example Balandrán-Quintana, Mendoza-Wilson, Vargas-Arispuro, \& Martínez-Telléz (2007) reported an increase in the activity of polygalacturonase enzyme leading to depolymerization of pectin during senescence of Zucchini (Cucurbita pepo L) stored at $2.5^{\circ} \mathrm{C}$ and $12^{\circ} \mathrm{C}$ for 16 days. Jariene, Danilčenko, Vaitkevičienè, \& Nataliia (2015) reported a decrease in dry matter of great pumpkins (Cucurbita maxima D) during storage at $15^{\circ} \mathrm{C}$ and $70 \%$ relative humidity for four months. However, commercially pumpkins are stored in the open at ambient temperatures. Rahman, Miaruddin, Khan, Masud, \& Begum (2013) reported an initial increase in total soluble solids until 45 days of storage followed by a decrease in titratable acidity, weight, $\beta$-carotene, and ascorbic acid of BARI pumpkin (Cucurbita moschata Poir) during storage at ambient conditions $\left(27-31^{\circ} \mathrm{C}\right.$ and $75-90 \%$ relative humidity) for a period of 120days.

The postharvest stability of the different pumpkin varieties varies depending on the composition of the peel and 
the flesh. According to Kader and Barret (2004), fruits generally differ in chemical constituent such as metabolizable carbohydrates, and pectin and in the expression of metabolic enzymes. This is likely to impact differently on their stability postharvest. The peel of fruits is reported to regulate the rate of transpiration and respiration, the key deteriorative processes postharvest (Kader \& Barret, 2004). Hence, differences in peel structural components such as cellulose, hemicellulose and lignin and their degradation are likely to affect the postharvest stability of different fruits.

The pumpkin fruit peel and flesh is the key distinguishing feature between species and varieties. However, there is dearth of knowledge about the fruit peel and flesh characteristics of the different varieties and how these relate to the postharvest stability of the different pumpkin varieties. To address these knowledge gaps, the changes in composition of the peel, flesh and the structure changes of the flesh of mature fruits of Cucurbita maxima Duchesne subsp maxima, Cucurbita pepo L var. fastigata and Cucurbita moschata Decne stored at ambient conditions were studied over a storage period of 8months. The results of this study will increase our understanding of the variability in Cucurbita spp but also form a basis for tapping into the commercial potential of the different pumpkin varieties.

\section{Materials and Methods}

\subsection{Raw Material Selection and Experimental Design}

Three pumpkin varieties namely $C$. maxima Duchesne subsp maxima, C. pepo $\mathrm{L}$ var. fastigata and $C$. moschata Decne varieties were grown on randomized plots on a farm in Luwero district, Central Uganda. The experiment was conducted in triplicate. Fruits were harvested at maturity (drying of the tendrils next to the fruit was used as the maturity index). Mature and defect free fruits weighing about 3.0 to 3.6kg (C. maxima Duchesne subsp maxima), 2.6 to $3.1 \mathrm{~kg}$ (C. pepo L var. fastigata) and 3.2 to $3.3 \mathrm{~kg}$ (C. moschata Decne) were stored at ambient conditions $\left(28^{\circ} \mathrm{C}\right.$ average temperature and $78 \%$ Relative humidity) for 8months. At monthly intervals, three fruits of each variety were randomly picked and monitored for change in cellulose, hemicellulose, lignin, starch, sugars, pectin esterification, polygalacturonase activity, moisture, and cell microscopy.

\subsection{Test Methods}

\subsubsection{Cellulose, Hemicellulose and Lignin Content of the Peel}

Cellulose, hemicellulose and lignin were determined as described by Van Soest and Robertson (1990). Pumpkin peel dried at $60^{\circ} \mathrm{C}$ was finely ground and $0.5 \mathrm{~g}$ weighed into a crucible and $100 \mathrm{ml}$ of neutral detergent solution, $0.5 \mathrm{~g}$ of sodium sulfite and three drops of n-octanol added. The mixture was heated to boiling, refluxed for $60 \mathrm{~min}$, filtered and the residue washed thrice with boiling water, then twice with cold acetone. Residue was dried for $8 \mathrm{hr}$ at $105^{\circ} \mathrm{C}$, cooled in a desiccator and weighed. The neutral detergent fibre, composed of cellulose, hemicellulose, lignin and fibre bound compounds was calculated using equation 1.

$$
\operatorname{NDF}(\%)=\frac{\text { Weight of residue after treatment with neutral detergent solution }}{\text { Weight of sample }} \times 100
$$

To determine the acid detergent fibre (ADF), $0.5 \mathrm{~g}$ of ground sample was weighed into a crucible, $100 \mathrm{ml}$ of acid detergent solution, three drops of n-octanol were added, heated to boiling and refluxed for $60 \mathrm{~min}$. The mixture was filtered, the residue washed thrice with boiling water, then twice with cold acetone. The Acid detergent fibre (residue, composed of cellulose, lignin and minerals), was dried at $105^{\circ} \mathrm{C}$ for $8 \mathrm{hr}$, cooled and weighed and calculated using equation 2 .

$$
\text { ADF }(\%)=\frac{\text { Weight of residue after treatment with acid detergent solution }}{\text { Weight of sample }} \times 100
$$

Hemicellulose and cellulose were determined as shown in equations 3 and 4 respectively. Lignin was determined after treating the Acid detergent fibre with $72 \%$ sulphuric acid for $3 \mathrm{hr}$ with occasional stirring. The remaining residue, composed of lignin and minerals was oven-dried at $105^{\circ} \mathrm{C}$ for $8 \mathrm{hr}$, incinerated in a muffle furnace at $550^{\circ} \mathrm{C}$ for $3 \mathrm{hr}$ and ash content calculated as shown in equation 5 .

$$
\begin{gathered}
\text { Hemicellulose }(\%)=\mathrm{NDF}(\%)-\mathrm{ADF}(\%) \\
\text { Cellulose }(\%)=\mathrm{ADF}(\%)-\text { Residue }(\%) \text { of ADF treated with } 72 \% \text { sulphiric acid } \\
\text { Lignin }(\%)=\text { Residue(\%) of ADF treated with } 72 \% \text { sulphiric acid - Ash }(\%)
\end{gathered}
$$

\subsubsection{Starch in Pumpkin Flesh}

Starch was quantified using the amyloglucosidase/ $\alpha$-amylase method as per Megazyme total starch assay kit 
(Megazyme, 2016). To finely grated pumpkin $(0.1 \mathrm{~g})$ in a test tube, $5 \mathrm{ml}$ of $80 \%(\mathrm{v} / \mathrm{v})$ ethanol was added, incubated at $80^{\circ} \mathrm{C}$ for $5 \mathrm{~min}$, vortexed, $5 \mathrm{ml}$ of $80 \%(\mathrm{v} / \mathrm{v})$ ethanol added, centrifuged (Fischer scientific 225 centrifuge, Fisher Scientific Co. St. Louis, MO) for 10min at 1141xg and supernatant discarded to get rid of any D-glucose and maltodextrins. Then $3 \mathrm{ml}$ of $1: 30$ mixture of thermostable amylase and $100 \mathrm{mM}$ sodium acetate buffer $\mathrm{pH} 5$ was added, incubated in a boiling water bath for $6 \mathrm{~min}$ to hydrolyse starch to maltodextrins, cooled to $50^{\circ} \mathrm{C}, 0.1 \mathrm{ml}$ amyloglucosidase added and held at $50^{\circ} \mathrm{C}$ in a water bath for $30 \mathrm{~min}$ to hydrolyse maltodextrins to D-glucose. Tube contents were reconstituted to $100 \mathrm{ml}$ using distilled water and an aliquot centrifuged at $1141 \mathrm{xg}$ for $10 \mathrm{~min}$. To each $0.1 \mathrm{ml}$ of filtrate, glucose standard and distilled water (blank), $3 \mathrm{ml}$ of glucose oxidase peroxidase (GOPOD) was added to oxidize glucose to D-gluconate and hydrogen peroxide. Hydrogen peroxide produces a quinoneimine dye whose absorbance was read at 510nm (Genesys 10S UV Visible spectrophotometer, Thermo Electron Corporation USA) and used in determining the starch content as shown in equation 6.

$$
\operatorname{Starch}(\%)=\Delta \mathrm{A} \times \frac{0.1}{\left(\mathrm{Agc}_{\mathrm{gc}}-\mathrm{A}_{\mathrm{b}}\right)} \times \frac{\mathrm{FV}}{0.1} \times \frac{100}{\mathrm{~W}} \times \frac{162}{180}
$$

Where; $\Delta \mathrm{A}=$ absorbance sample-absorbance blank: $\mathrm{W}=$ weight of sample $(\mathrm{mg}): \mathrm{FV}=$ final volume $(100 \mathrm{ml})$ : $\mathrm{A}_{\mathrm{gc}}=$ absorbance glucose control: $\mathrm{A}_{\mathrm{b}}=$ absorbance blank:

$$
\frac{100}{W}=\text { factor to express starch as a percentage of sample }
$$

$$
\frac{162}{180}=\text { adjustment from free } \mathrm{D}-\text { glucose to anhydro } \mathrm{D}-\text { glucose of starch }
$$

\subsubsection{D-glucose, D-fructose and Sucrose}

D-glucose, D-fructose and sucrose were determined spectrophotometrically at 340nm (Genesys 10S UV Visible spectrophotometer, Thermo Electron Corporation USA) as described in the Megazyme D-glucose, D-fructose and sucrose assay kit (Megazyme, 2014). Finely grated pumpkin flesh (5g) was slurred to one litre using distilled water, filtered using Whatman filter paper, $0.1 \mathrm{ml}$ filtrate pipetted into a test tube, $2.1 \mathrm{ml}$ distilled water was added, then $0.1 \mathrm{ml}$ buffer and $0.1 \mathrm{ml}$ of nicotinamide adenine dinucleotide phosphate and adenosine 5 triphosphate (NADP $/ \mathrm{ATP})$. Absorbance $\mathrm{A}_{1}$ of mixture was read after $3 \mathrm{~min}$. To the above mixture, $20 \mu 1$ of a mixture of hexokinase and glucose 6 phosphate dehydrogenase was added, mixed and absorbance $A_{2}$ read after $5 \mathrm{~min}$. Glucose was quantified as shown in equations 7 and 8.

In presence of hexokinase and adenosine 5 triphosphate, fructose in the above sample is phosphorylated to fructose 6 phosphate. Phosphoglucose isomerase $(20 \mu \mathrm{l})$ was added to isomerize fructose 6 phosphate to glucose 6 phosphate which reacts with nicotinamide adenine dinucleotide phosphate forming gluconate 6 phosphate and reduced nicotinamide adenine dinucleotide phosphate leading to a rise in absorbance that was read after 10min $\left(A_{3)}\right.$ and used to quantify fructose as shown in equation 9.

$$
\begin{gathered}
\text { Glucose }(\mathrm{g} / \mathrm{L})=\frac{2.42 \times 180.16}{6300 \times 1 \times 0.1} \times\left(\mathrm{A}_{2}-\mathrm{A}_{1}\right)_{\text {sample }}-\left(\mathrm{A}_{2}-\mathrm{A}_{1}\right)_{\text {blank }} \times \mathrm{F} \\
\text { Glucose }(\mathrm{g} / 100 \mathrm{~g})=\frac{\text { Concetration glucose }_{(\mathrm{g} / \mathrm{l})}}{\text { sample weight }_{(\mathrm{g} / \mathrm{l})}} \times 100
\end{gathered}
$$

Where; 2.42 = final volume of the mixture $(\mathrm{ml}): 180.16=$ molecular weight of glucose $(\mathrm{g} / \mathrm{mol}): 1=$ light path $(1 \mathrm{~cm}): 0.1=$ sample volume $(\mathrm{ml}): \mathrm{F}=$ dilution factor $(200)$ : and $6300=$ extinction coefficient of NADPH at 340 $\mathrm{nm}\left(1 \mathrm{x} \mathrm{mol}^{-1} \mathrm{x} \mathrm{cm}^{-1}\right)$.

$$
\text { Fructose }(g / L)=\frac{2.44 \times 180.16}{6300 \times 1 \times 0.1} \times\left(A_{3}-A_{2}\right)_{\text {sample }}-\left(A_{3}-A_{2}\right)_{\text {blank }} \times F
$$

Where; $2.44=$ final volume of the mixture in the cuvette $(\mathrm{ml}): 180.16=$ molecular weight of fructose $(\mathrm{g} / \mathrm{mol})$

Sucrose was determined from the difference in absorbance for D glucose concentration before and after hydrolysis of sucrose to glucose. To the test tubes except for blank, $0.1 \mathrm{ml}$ slurred filtered sample was added. Beta fructosidase $(0.2 \mathrm{ml})$ was added, mixed and held at $30^{\circ} \mathrm{C}$ for $5 \mathrm{~min}$ followed by $2 \mathrm{ml}$ distilled water, $0.1 \mathrm{ml}$ buffer and $0.1 \mathrm{ml}$ of $\mathrm{NADP}^{+} / \mathrm{ATP}$. Absorbance of the mixture $\left(\mathrm{A}_{1}\right)$ was read after $3 \mathrm{~min}$, a mixture of hexokinase and glucose 6 phosphate dehydrogenase $(0.02 \mathrm{ml})$ added, mixed and absorbance $A_{2}$ read after $5 \mathrm{~min}$. Sucrose was 
quantified as shown in equation 10.

$$
\begin{aligned}
& \text { Sucrose }(\mathrm{g} / \mathrm{L})=\frac{2.42 \times 342.3}{6300 \times 1 \times 0.1} \times \Delta \mathrm{A}_{\text {sucrose }} \times \mathrm{F}
\end{aligned}
$$

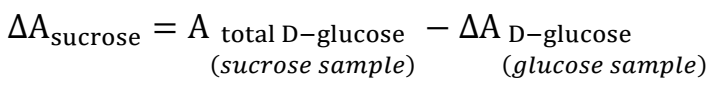

$$
\begin{aligned}
& \underset{\text { total D-glucose }}{\Delta \mathrm{A}_{\text {sucrose sample })}}=\left(\mathrm{A}_{2}-\mathrm{A}_{1}\right)_{\text {sample }}-\left(\mathrm{A}_{2}-\mathrm{A}_{1}\right)_{\text {blank }}
\end{aligned}
$$

Where; $342.3=$ molecular weight of sucrose $(\mathrm{g} / \mathrm{mol}): \Delta \mathrm{A}_{\text {Sucrose }}=$ change in absorbance for sucrose sample change in absorbance for glucose sample.

\subsubsection{Pectin's degree of Esterification}

Pectin was extracted as described by Fertonani et al., (2006). To $5 \mathrm{~g}$ of pumpkin flesh dried overnight at $70^{\circ} \mathrm{C}$ and finely ground, $10 \mathrm{ml}$ of $70 \%$ ethanol was added, mixed, $100 \mathrm{ml}$ distilled water added followed by $100 \mathrm{ml}$ of $210 \mathrm{mM}$ hot nitric acid solution, stirred for $10 \mathrm{~min}$, and cooled to $4^{\circ} \mathrm{C}$. Pectin was precipitated by slowly pouring the mixture into a beaker containing ethanol to a final proportion of $1: 3(\mathrm{v} / \mathrm{v})$ of pectin solution: ethanol. Mixture was filtered using a cheese cloth, pectin put in $70 \%$ ethanol overnight to remove the remaining acid, filtered using filter paper and oven dried at $30^{\circ} \mathrm{C}$ for $8 \mathrm{hr}$ and then overnight at $60^{\circ} \mathrm{C}$.

Free carboxy groups $\left(\mathrm{K}_{\mathrm{f}} \%\right)$ and esterified carboxy groups $\left(\mathrm{K}_{\mathrm{e}} \%\right)$ were determined using potentiometric titration method (Bochek, Zabivalova, \& Petropavlovskii, 2001). Dried pectin $(0.2 \mathrm{~g})$ was wetted with ethanol, $20 \mathrm{ml}$ distilled water at $40^{\circ} \mathrm{C}$ added, stirred for $2 \mathrm{hr}$, titrated with $0.1 \mathrm{~N} \mathrm{NaOH}$ in the presence of phenolphthalein to a pale rose color and titre used to determine free carboxy groups $\left(\mathrm{K}_{\mathrm{f}} \%\right)$. Then $10 \mathrm{ml}$ of $0.1 \mathrm{~N} \mathrm{NaOH}$ solution was added, stirred for $2 \mathrm{hr}$ to saponify the esterified carboxy groups, $10 \mathrm{ml}$ of $0.1 \mathrm{~N} \mathrm{HCl}$ added, the excess $\mathrm{HCl}$ titrated with $0.1 \mathrm{~N} \mathrm{NaOH}$ and titre used to calculate esterified carboxy groups $\left(\mathrm{K}_{\mathrm{e}} \%\right)$ as shown in equation 11 . The degree of esterification was calculated using equation 12 .

$$
\begin{gathered}
\mathrm{K}_{\mathrm{f}} \text { or } \mathrm{K}_{\mathrm{e}}(\%)=\frac{\mathrm{N}_{\mathrm{NaOH}} \times \mathrm{V}_{\mathrm{NaOH}} \times 0.045}{\mathrm{a}} \times 100 \\
\mathrm{DE}(\%)=\frac{\mathrm{K}_{\mathrm{e}}}{\mathrm{K}_{\mathrm{t}}} \times 100
\end{gathered}
$$

Where $\mathrm{K}_{\mathrm{t}}$ (total carboxyl groups $(\%)=\mathrm{K}_{\mathrm{f}}+\mathrm{K}_{\mathrm{e}}$ and DE is the degree of esterification:

$a$ is the sample weight of pectin

$\mathrm{N}_{\mathrm{NaOH}}$ and $\mathrm{V}_{\mathrm{NaOH}}$ are the normality and volume (ml) of sodium hydroxide, respectively.

\subsubsection{Polygalacturonase Activity}

Crude extracts with polygalacturonase activity were obtained by washing $10 \mathrm{~g}$ grated pumpkin in $30 \mathrm{ml}$ cold $1 \%$ sodium bisulphite, thrice. The residue mixed with $30 \mathrm{ml}$ of $1 \mathrm{M}$ sodium chloride, $\mathrm{pH}$ adjusted to 6.0 using $0.1 \mathrm{~N}$ $\mathrm{NaOH}$, held at $2.5^{\circ} \mathrm{C}$ for $2 \mathrm{hr}$, stirring occasionally and centrifuged (Fischer scientific 225 centrifuge, Fisher Scientific Co. St. Louis, MO) at $10,062 \mathrm{xg}$ for $10 \mathrm{~min}$. The supernatant $(200 \mu \mathrm{l})$ was reacted with of $0.025 \%$ polygalacturonic acid (LM-106 AS-YA GENU pectin, CPKelco, Lille Skensved-Denmark) at $30^{\circ} \mathrm{C}$ for $1 \mathrm{hr}$, cold borate buffer $\mathrm{pH} 10(1 \mathrm{ml})$ added then $200 \mu \mathrm{l}$ of $1 \%$ cyanoacetamide, held in a boiling water bath for $10 \mathrm{~min}$, cooled to room temperature and the absorbance read at 276nm (Genesys 10S UV Visible spectrophotometer, Thermo Electron Corporation USA). A blank, and standard curve for D-galacturonic acid were also prepared. The enzyme activity was reported as $\mu$ mol of D-galacturonic acid produced in $1 \mathrm{hr}$ (Gross, 1982).

\subsubsection{Moisture Loss}

A sample (2g) of peel and flesh was weighed into a moisture dish, dried in a hot air oven at $105^{\circ} \mathrm{C}$ for $16 \mathrm{hr}$ and moisture content (\%) determined using the following equation (Bradley, 2003). Monthly average moisture loss was computed and expressed as a percentage of the initial using equation 13.

$$
\% \text { Moisture }\left(\frac{w t}{w t}\right)=\frac{\text { weight of wet sample-weight dry sample }}{\text { weight of wet sample }} \times 100
$$

2.2.7 Microscopy of Cells and Intercellular Spaces

A piece of the pumpkin was cut transversely from three fruits of the different pumpkin varieties, trimmed to 
completely remove traces of peel and soft regions of the ovary wall where seeds attach, leaving a piece of about $1 \mathrm{~cm}^{3}$. The $1 \mathrm{~cm}^{3}$ piece was fixed in cold formalin: acetic acid: ethanol solution $(2: 1: 10 \mathrm{v} / \mathrm{v})$ for $7.8 \mathrm{hr}$. Thin $(5 \mathrm{~mm})$ sections were cut, subjected to $7.8 \mathrm{hr}$ tissue processing in a tissue processor (SLEE mtp, SLEE MAINZ, Germany) and then embedded in paraffin wax (Bio-plast, Bioptica, Italy) before sectioning $(3 \mu \mathrm{m})$ using a rotary microtome (cut 4062, SLEE MAINZ Germany). Sections were deparaffinized and stained using Toluidine Blue as described by Li et al., (2017). Stained sections were viewed using a Nikkon Eclipse E800 light microscope with a camera (Isaza, Barcelona, Spain) at a magnification of $\mathrm{x} 40$ and micrographs taken. Area occupied by intercellular spaces was determined using ImageJ/Fiji 1.46 software.

\subsection{Statistics}

All data analysis was done using Minitab 18 statistical software. One way ANOVA analysis was done to compare the differences between varieties at different storage times and mean separation was done using the Tukey Pairwise Comparisons method $(\mathrm{p} \leq 0.05)$ in order know which varieties differed significantly. In addition, One way ANOVA was used to compare different times of storage within the same variety and Mean separation was done in order know after how long a significant difference existed in a given parameter of a particular variety. Factor analysis using principal components was carried out on the mean values of the 12 quality parameters to obtain the major determinants of postharvest stability.

\section{Results}

\subsection{Cellulose, Hemicellulose and Lignin Content of the Peel}

Initial cellulose content varied significantly $(p<0.05)$ with $C$. maxima Duchesne subsp maxima having the highest and $C$. pepo L var. fastigata the least. In the 8months, cellulose decreased by $41.7 \%$ in $C$. maxima Duchesne subsp maxima, $50.4 \%$ in C. pepo L var. fastigata and $67.9 \%$ in C. moschata Decne (Figure 1A). A significant decrease in each variety was observed after 4 months, 3 months and 2 months respectively.

Initial hemicellulose content varied significantly $(p<0.05)$ with $C$. maxima Duchesne subsp maxima having the highest and C. moschata Decne the least. Hemicellulose reduced with storage (Figure 1B). C. maxima Duchesne subsp maxima lost $75.3 \%$ of its hemicellulose, C. pepo L var. fastigata lost $96.1 \%$ and C. moschata Decne lost $97.7 \%$ with significant reductions after 4 months, 3months and 2months, respectively.

Initial varietal lignin content did not differ (Figure 1C), and increased significantly after 4months of storage. Lignin increased by $15.9 \mathrm{gkg}^{-1} \mathrm{FWB}$ in C. maxima Duchesne subsp maxima, $6.0 \mathrm{gkg}^{-1} \mathrm{FWB}$ in C. pepo L var. fastigata and $8.8 \mathrm{gkg}^{-1} \mathrm{FWB}$ in C. moschata Decne. 

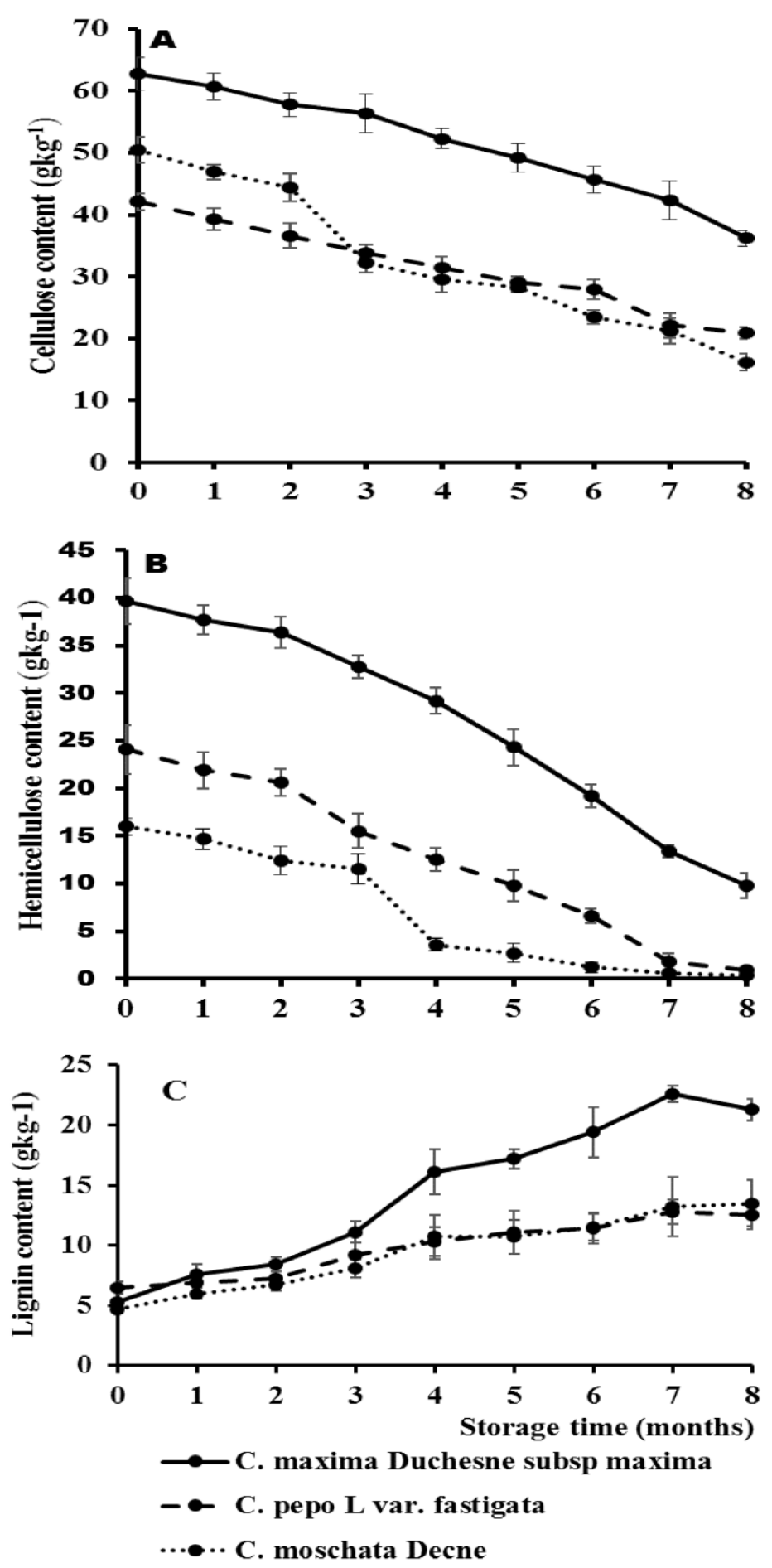

Figure 1. Change in cellulose (A), hemicellulose (B) and lignin (C) content of the pumpkins peel during storage

\subsection{Starch, D-glucose, D-fructose and Sucrose Content of the Flesh}

Initial starch content varied significantly among varieties and decreased during storage. $C$. maxima Duchesne subsp maxima had highest $(p<0.05)$ starch content and $C$. moschata Decne the least throughout the storage period (Figure 2A). In all the three varieties, starch breakdown was fastest from 0-3months of storage.

The initial glucose level of $C$. maxima Duchesne subsp maxima and C. moschata Decne was not statistically different but $C$. pepo L var. fastigata had significantly higher glucose. Glucose level in C. maxima Duchesne subsp maxima and C. moschata Decne increased to a peak at 4 to 5 months and then decreased. However, the 
glucose content in C. pepo L var. fastigata remained fairly constant throughout (Figure 2B).

Varietal sucrose content initially varied significantly, with $C$. maxima Duchesne subsp maxima having the highest. Sucrose content decreased during storage (Figure 2C) for all varieties. In both C. maxima Duchesne subsp maxima and C. moschata Decne, the rate of sucrose breakdown was highest from 0-5months of storage with respective slopes of 5.1 and $3.8 \mathrm{gkg}^{-1} \mathrm{month}^{-1}$. Sucrose breakdown then changed to 4.6 and $3.4 \mathrm{gkg}^{-1} \mathrm{month}^{-1}$ for C. maxima Duchesne subsp maxima and C. moschata Decne, respectively. For C. pepo L var. fastigata the rate of sucrose breakdown was $2.2 \mathrm{gkg}^{-1} \mathrm{month}^{-1}$ from $0-5$ months and $2.6 \mathrm{gkg}^{-1} \mathrm{month}^{-1}$ from 5-8months of storage.

The initial fructose content of different varieties was the same. Fructose content generally increased to a peak at 4-6 months and then decreased among the varieties (Figure 2D).
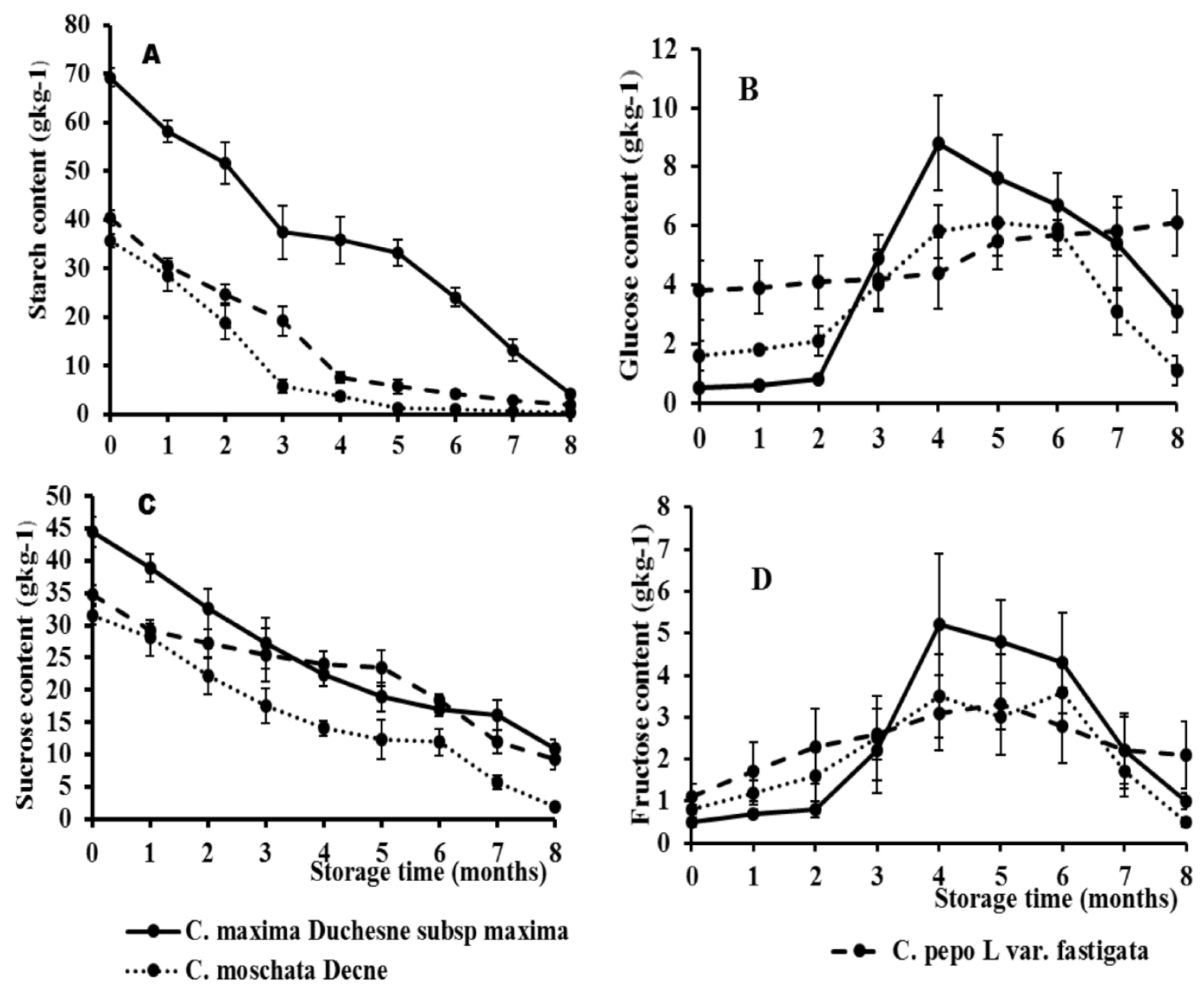

Figure 2. Change in carbohydrates content of the flesh of the pumpkin varieties during storage

\subsection{Degree of Esterification of Pectin}

The esterification of pectin of different varieties varied significantly $(p<0.05)$. C. pepo L var. fastigata had the most esterified pectin and C. moschata Decne the least. Generally, the degree of esterification reduced during storage (Figure 3A). The esterification of pectin reduced by 64.9, 57.4, and 48.6\% in C. moschata Decne, C. maxima Duchesne subsp maxima and C. pepo L var. fastigata respectively. 

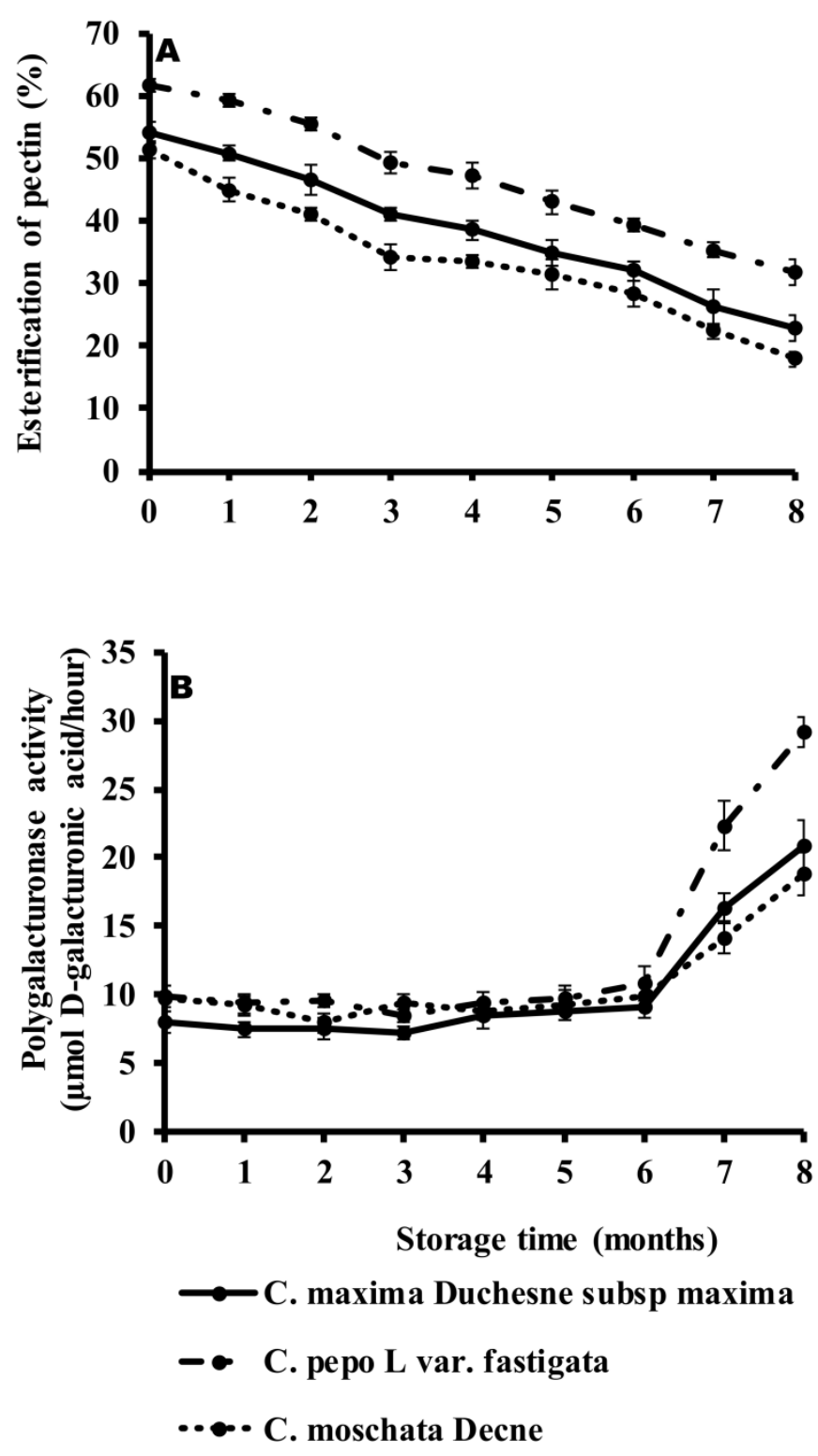

Figure 3. Change in degree of esterification of pectin (A) and polygalacturonase activity (B) of the flesh of different pumpkin varieties during storage

\subsection{Polygalacturonase Activity}

Polygalacturonase activity was the same, remained constant until the $7^{\text {th }}$ month when it increased. C. pepo $\mathrm{L}$ var. fastigata registered higher enzyme activity than C. moschata Decne and C. maxima Duchesne subsp maxima, which were statistically not different between 7 and 8 months of storage (Figure 3B).

\subsection{Moisture Loss}

The initial moisture content of the flesh of the three pumpkin varieties was statistically the same and ranged from 900 to $924 \mathrm{gkg}^{-1}$. Also the moisture content of the peel did not differ ( $\mathrm{p}<0.05$ ), ranging from 890 to $910 \mathrm{gkg}^{-1}$. Cumulative moisture lost from flesh and peel increased with storage. Statistical difference in cumulative moisture loss of the peel was detectable starting from $5^{\text {th }}$ month but that from the flesh was not statistically different throughout storage (Figure 4). 


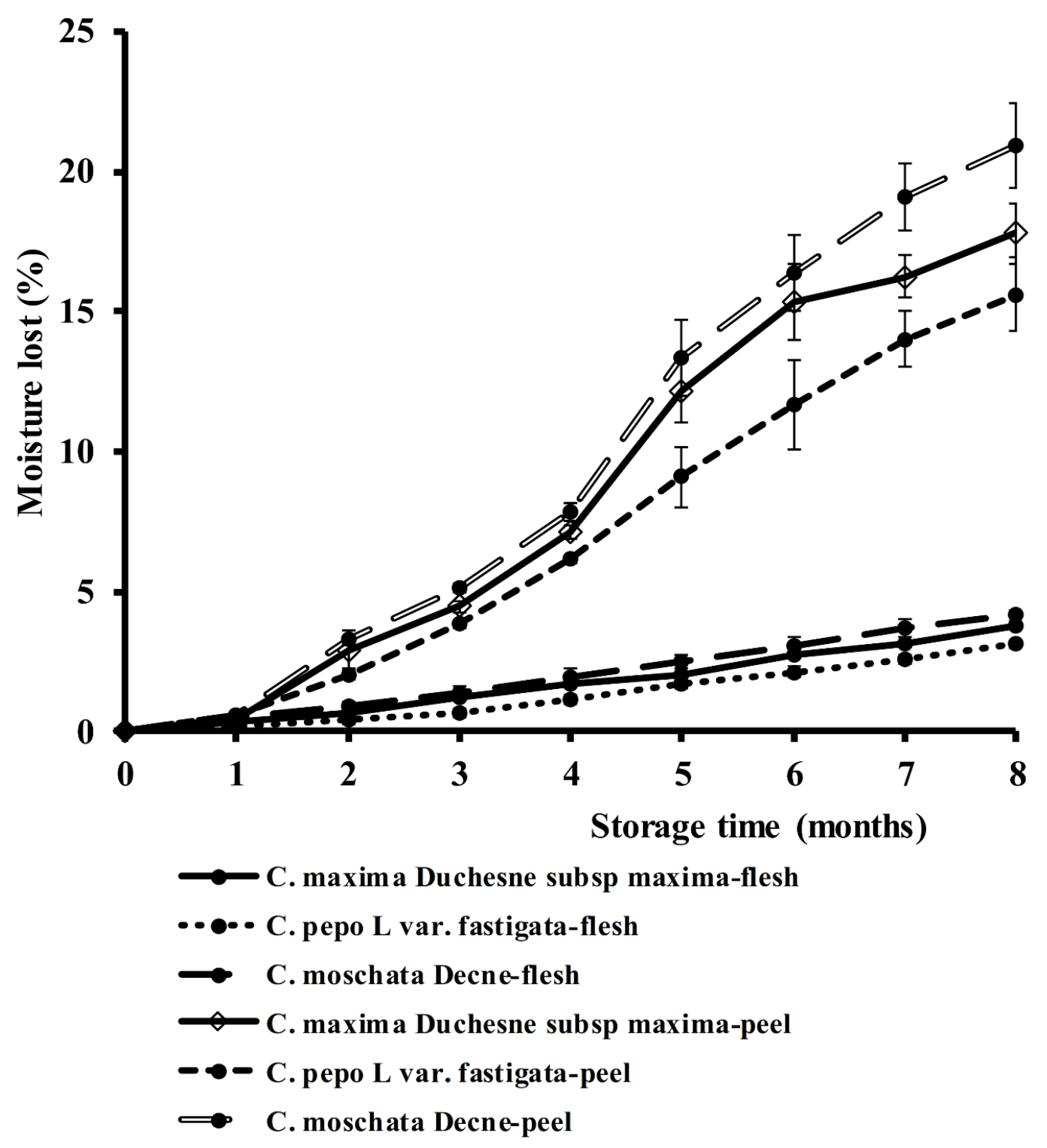

Figure 4. Cumulative moisture (\%) lost from the peel and flesh of different pumpkin varieties during storage

\subsection{Microscopy of Cells and Intercellular Spaces}

The area occupied by intercellular spaces (\%) in all the three varieties was not statistically different at month zero. The size of intercellular spaces increased with storage (Table 1). The degree of cell separation was most pronounced in C. moschata Decne and by the sixth month, cells had started shrinking and the cell walls shriveled (Figure 5). 
Table 1. Area of intercellular spaces (\%) in three pumpkin varieties stored for 8 months

\begin{tabular}{llll}
\hline Month & C. maxima Duchesne subsp maxima & C. pepo L var. fastigata & C. moschata Decne \\
\hline 0 & $1.0^{\mathrm{a}} \pm 0.1$ & $0.9^{\mathrm{a}} \pm 0.1$ & $0.9^{\mathrm{a}} \pm 0.1$ \\
1 & $1.1^{\mathrm{ab}} \pm 0.2$ & $1.0^{\mathrm{b}} \pm 0.1$ & $1.4^{\mathrm{a}} \pm 0.1$ \\
2 & $1.6^{\mathrm{ab}} \pm 0.1$ & $1.4^{\mathrm{b}} \pm 0.1$ & $1.9^{\mathrm{a}} \pm 0.2$ \\
3 & $2.1^{\mathrm{ab}} \pm 0.1$ & $1.9^{\mathrm{b}} \pm 0.1$ & $2.6^{\mathrm{a}} \pm 0.2$ \\
4 & $2.6^{\mathrm{a}} \pm 0.1$ & $2.2^{\mathrm{b}} \pm 0.1$ & $2.9^{\mathrm{a}} \pm 0.2$ \\
5 & $2.8^{\mathrm{a}} \pm 0.1$ & $2.4^{\mathrm{b}} \pm 0.1$ & $3.5^{\mathrm{c}} \pm 0.1$ \\
6 & $3.3^{\mathrm{a}} \pm 0.4$ & $2.9^{\mathrm{a}} \pm 0.1$ & $5.0^{\mathrm{b}} \pm 0.2$ \\
7 & $3.9^{\mathrm{ab}} \pm 0.2$ & $3.5^{\mathrm{b}} \pm 0.3$ & $4.3^{\mathrm{a}} \pm 0.3$ \\
8 & $3.0^{\mathrm{a}} \pm 0.2$ & $4.0^{\mathrm{b}} \pm 0.2$ & $3.5^{\mathrm{ab}} \pm 0.3$ \\
\hline
\end{tabular}

Data are means of triplicate parameter values \pm standard deviation. Means in the same row with the same letter are significantly different $(\mathrm{P} \leq 0.05)$

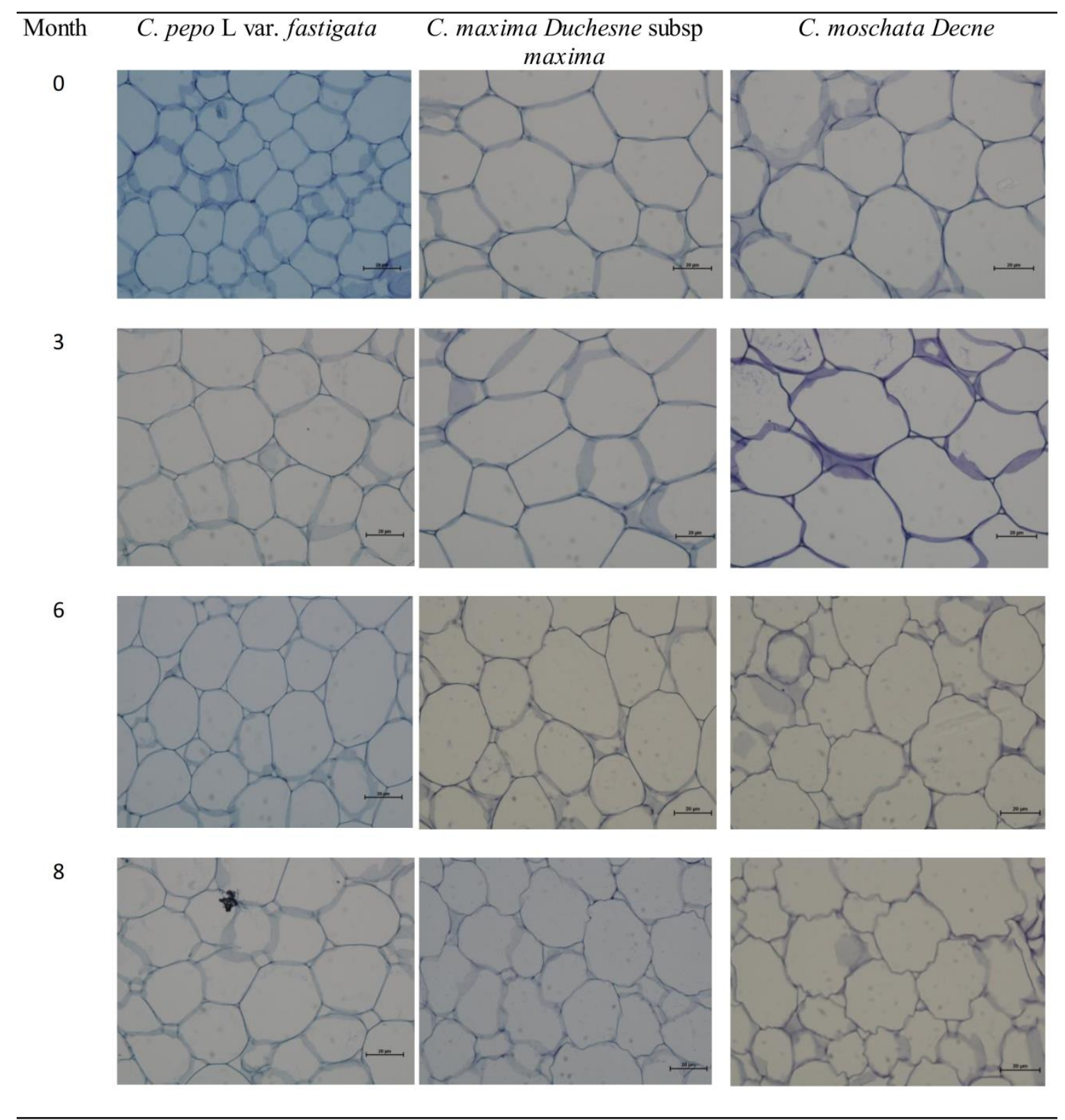

Figure 5. Change in appearance of cells and size of intercellular spaces of the flesh of three pumpkin varieties during the eight months of storage 


\subsection{The Major Determinants of Postharvest Stability as Determined by Factor Analysis}

Factor analysis revealed that factors 1 and 2 accounted for $64.9 \%$ and $16.1 \%$ of the total variation, respectively. Reduction in sucrose, esterification of pectin, starch, hemicellulose and cellulose had strong negative association with Factor 1 (Figure 6A), with factor loadings of $-0.97,-0.88,-0.87,-0.82$ and -0.79 respectively. These were the major changes from 0 to 3 months (Figure 6B). Moisture loss from the flesh and peel, change in size of intercellular spaces, breakdown of glucose and fructose positively associated with Factor 1 from 4 to 7 months, with factor loadings of $0.95,0.94,0.93,0.51$, and 0.37 respectively. Yet polygalacturonase activity solely positively associated with Factor 1 (0.64) from 7 to 8months.
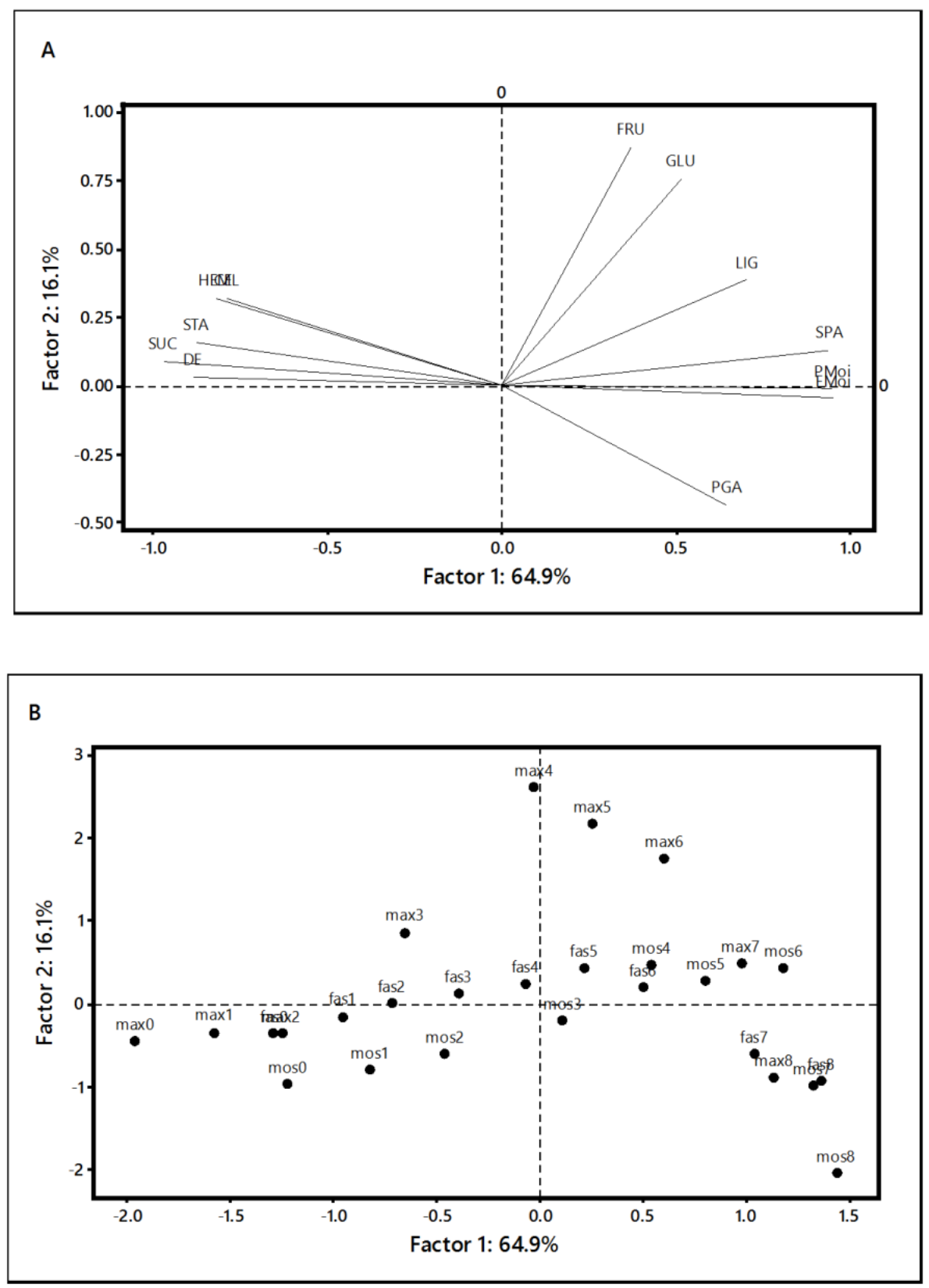

Figure 6. Loading plot (A) contribution of the different parameters to postharvest stability and score plot (B) position of the three varieties at different storage times in the quadrants of the multivariate space of the first 2 factors

FRU: fructose; GLU: glucose; LIG: lignin; SPA: size of intercellular spaces; PMoi: peel moisture; FMoi: flesh moisture; PGA: polygalacturonase activity; DE: pectin's degree of esterification; SUC: sucrose; STA: starch HEM: hemicellulose and CEL: cellulose. Max 0 to 8; Fas 0 to 8; and Mos 0 to 8 refer to C. maxima Duchesne subsp maxima, C. pepo L. var fastigata and C. moschata Decne at 0 to $8^{\text {th }}$ month of storage respectively. 


\section{Discussion}

\subsection{Cellulose, Hemicellulose and Lignin Content of the Peel}

Cellulose and hemicellulose results (Figure 1) agree with those of Jariene et al. (2015) who observed a significant decrease in crude fibre of stored pumpkins. Plant cell walls reportedly comprise of $90 \%$ polysaccharides namely cellulose, hemicellulose and pectin. Hemicellulose especially xyloglucan tethers cellulose microfibrils through hydrogen bonds thus reinforcing the cell wall. Hydrolysis of cellulose is slow in orderly, well bound cellulose microfibrils but hemicellulases reportedly alter ligation of hemicelluloses to cellulose in addition to cleaving the backbone of hemicelluloses (Goulao \& Oliveira, 2008). This possibly explains why C. moschata Decne that had the least hemicellulose content also had the highest decrease in cellulose and hence deteriorated fastest. By the $4^{\text {th }}$ month, C. maxima Duchesne subsp maxima, C. pepo L var. fastigata and C. moschata Decne had lost $16.6 \%, 25.2 \%$ and $41.5 \%$ of their cellulose, respectively. Besides, it is the degradation of cellulose microfibrils that leads to breakdown of cell walls and their eventual disintegration (NCBE, 2000) and cellulase enzyme activity was reported to increase towards ripening of pumpkin fruit (Sharma \& Rao, 2013).

The observed increase in lignin could be attributed to continued lignification of cells postharvest (Cai et al., 2006) coupled with moisture loss from the peel that concentrates the matrix. An increment in liginification was also observed in postharvest storage of 'Luoyangqing' loquat fruits (Cai et al., 2006). Besides degradative changes in the plant cell wall are reported to occur in cellulose, hemicellulose and pectin not lignin (Goulao, Almeida, \& Oliveira, 2010).

\subsection{Starch, D-glucose and Sucrose Content of the Flesh}

Starch and sucrose pattern observed is in agreement with Jariene et al., (2015) who reported a decrease in dry matter during storage of different pumpkin cultivars. Wills, Lim, $-\&$ Greenfield (1984) also observed a decrease in starch of Cavendish bananas during storage but in about 7days, nearly all the starch had been converted to sugars unlike in the studied pumpkins. This is explained by the fact that pumpkins are non-climacteric whereas bananas are climacteric fruits hence bananas characterized by an increase in respiration postharvest (Kader \& Barret, 2004).

The pattern observed in glucose and fructose in this study is in agreement with that of Rahman et al., (2013), where total soluble solids of $C$. moschata Poir increased until 1.5 months and then decreased. Initial increase in glucose and fructose despite their utilization in respiration was attributable to breakdown of starch and sucrose. Probably at that stage, the rate of generation of glucose from starch and sucrose as well as fructose from sucrose was greater than the rate of glucose and fructose breakdown. Respiration is an oxidative process and conventionally, glucose is the compound that is preferentially involved in the initial oxidative step. Starch is degraded first to glucose while sucrose is hydrolysed to glucose and fructose that are then oxidised to other respiratory substrates (Kader \& Barret, 2004). All pumpkin varieties were principally starchy at harvest, with low levels of readily metabolizable sugars. The high starch and sucrose breakdown from 2 to 3 months and from 2 to 4 months, respectively was concomitant with the peak in glucose and fructose from 4 to 5 months.

The rate of respiration indicates metabolic activity of the tissue (Stitt \& Sonnewald, 1995) and thus a useful guide to storage life. Hence $C$. moschata Decne that had least starch and sucrose contents is likely to have a shorter postharvest life. Besides at 4months, $C$. maxima Duchesne subsp maxima, C. pepo L var. fastigata and C. moschata Decne had lost $48.3 \%, 81.1 \%$ and $89.7 \%$ of their starch and $49.6 \%, 30.7 \%$ and $55.5 \%$ of their sucrose respectively.

\subsection{Degree of Esterification of Pectin}

Esterification of pectin refers to the proportion of methyl groups present in the pectin (Bochek et al., 2001). The observed reduction in esterification of pectin during storage of pumpkins concurs with Gross \& Wallner (1979) who observed a reduction in methylation of pectin from $90 \%$ in green tomato to $35 \%$ in ripe fruit. Gross \& Wallner (1979) further reported the decrease in methylation of the pectin as one of the earliest detectable changes during ripening of fruits. The structural and compositional changes that occur to most fruit cell wall polymers during ripening are reported to have common features (Balandrán-Quintana et al., 2007) although progression is fastest in climacteric fruits than non-climacteric fruits (Kader \& Barret, 2004). The higher decrease in esterification in C. moschata Decne implies that C. moschata Decne either has a higher quantity of pectin methyl esterase enzyme or its pectin is more sensitive to the enzyme than other varieties. Pectin methylesterase is responsible for splitting methoxy groups off the pectin, forming less esterified pectin (NCBE, 2000).

\subsection{Polygalacturonase Activity}

Polygalacturonase activity remaining fairly constant for the first 6 months in all pumpkin varieties justifies a 
non-climacteric nature. This is explained by the fact that the transcription of polygalacturonase enzyme gets activated only during ripening and the progression of ripening is reportedly slow in non-climacteric fruits (Nicholass, Smith, Schuch, Bird, \& Grierson, 1995). Shooting-up in the $7^{\text {th }}$ month is in agreement with Balandrán-Quintana et al., (2007) who reported polygalacturonase enzyme to be majorly responsible for pectin depolymerization during senescence of non-climacteric fruits like Zucchini (Cucurbita pepo L). Despite showing highest degree of polygalacturonase activity, C. pepo L var. fastigata had least change in size of intercellular spaces, probably due to the high esterification making its pectin less sensitive to polygalacturonase enzyme (NCBE, 2000). Besides endo and exo-polygalacturonases only break bonds between the non-esterified galacturonic acid molecules (NCBE, 2000) yet the ease with which plant cells separate from one another depends on how easy pectin of the middle lamella can be solubilized (Goulao et al., 2010). This postulation also agrees with the study in which Scifresh and Royal Gala apple varieties were studied for cell wall structures leading to cultivar differences in softening rates. The tricellular junctions of Scifresh apple, a slow softening variety were found to be rich in highly esterified pectin thus stronger cell adhesion and increased resistance to development of large air spaces ( $\mathrm{Ng}$ et al., 2013).

Noteworthy, texture of fruits is derived from turgor pressure and from the middle lamella that holds cells together (Barrett, Beaulieu, \& Shewfelt, 2010). Turgor pressure is attributed to the moisture and starch contents of the cells. Loss of turgor pressure (Goulao et al., 2010) and degradation of pectin in the middle lamella (Mollendorf, Villiers, Jacobs, \& Westraad, 1993) are reported to result into a mealy texture. This implies that $C$. moschata Decne that exhibited the largest increase in size of air spaces and starch breakdown is likely to get mealy easily and also have a shorter postharvest life.

\subsection{Moisture Loss}

The highest moisture lost from the peel of C. moschata Decne was partly attributable to its low initial hemicellulose content and high hemicellulose and cellulose breakdown. Fruits cells majorly contain cellulose, hemicellulose and pectin. However some tissues also contain lignin (NCBE, 2000), for example the pumpkin peel but initial lignin did not vary among studied pumpkin varieties.

\subsection{The Major Determinants of Postharvest Stability as Determined by Factor Analysis}

Factor loadings show the relationship of each variable to the underlying latent factor, in this case the postharvest stability of pumpkins. Variables with strong association to postharvest stability of pumpkins are in the order of sucrose breakdown (-0.97), moisture loss from flesh (0.95) and peel (0.94), change in intercellular spaces (0.93), de-esterification of pectin (-0.88), breakdown of starch (-0.87), hemicellulose $(-0.82)$ and cellulose $(-0.79)$.

The position of the three varieties at different storage times in the quadrants of the multivariate space revealed $C$. maxima Duchesne subsp maxima of 0 to 3months, C. pepo L var. fastigata of 0 to 4 months and C. moschata Decne of 0 to 2 months to be strongly linked to reduction in sucrose, starch, cellulose, Hemicellulose, and esterification of pectin. This implies that these changes took place early in C. moschata Decne (2months) compared to other varieties hence $C$. moschata Decne likely to have a shorter postharvest life. In addition a strong association exited between $C$. maxima Duchesne subsp maxima of 5 to 7 months, C. pepo L var. fastigata of 5 to 6months and C. moschata Decne of 3 to 6months to moisture loss from the peel and change in size of intercellular spaces. This again shows that these changes took place early in C. moschata Decne compared to other varieties.

\section{Conclusion}

C. moschata Decne deteriorates fastest of all studied varieties. The postharvest stability of pumpkins is determined by an interplay of factors. The major cause of variation in stability of different pumpkin species were difference in rates of reduction in sucrose, starch, cellulose, hemicellulose, and esterification of pectin. These changes took place earliest in C. moschata Decne (2months) compared to other varieties. In addition $C$. moschata Decne of 3 to 6months was strongly associated with moisture loss from the peel. Generally pumpkin varieties with high hemicellulose content, which is meant to tether cellulose microfibrils will have slower rate of cellulose reduction hence delayed breakdown of the cell walls. This will in turn reduce the rate of moisture loss from the peel, and the rate of breakdown of sucrose and starch.

\section{Conflict of interest}

None

\section{Acknowledgements}

This work was made possible with funding from the German Academic Exchange Service (DAAD) 


\section{References}

Balandrán-Quintana, R. R., Mendoza-Wilson, A. M., Vargas-Arispuro, I., \& Martínez-Telléz, M. A. (2007). Activity of $\beta-$ Galactosidase and Polygalacturonase in Zucchini Squash (Cucurbita pepo L.) Stored at Low Temperatures. Food Technology and Biotechnology, 45, 396-401. https://doi.org/10.1080/10408391003626322

Barrett, D. M., Beaulieu, J. C., \& Shewfelt, R. (2010). Color, Flavor, Texture, and Nutritional Quality of Fresh-Cut Fruits and Vegetables: Desirable Levels, Instrumental and Sensory Measurement, and the Effects of Processing. Critical Reviews in Food Science and Nutrition, 50, 369-389.

Bochek, A. M., Zabivalova, N. M., \& Petropavlovskii, G. A. (2001). Determination of the Esterification Degree of Polygalacturonic Acid. Russian Journal of Applied Chemistry, 74, 796-799. https://doi.org/10.1023/A:1012701219447

Bradley, R. L. Jr. (2003). Moisture and Total Solids Analysis Chapter 6. In S. S. Nielsen (Ed). Food Analysis, $3^{\text {rd }}$ edition, (pp.81-98). Springer Science+Business Media, LLC: New York, USA

Cai, C., Chen, K., Xu, W., Zhang, W., Li, X., \& Ferguson, I. (2006). Effect of 1-MCP on postharvest quality of loquat fruit. Postharvest Biology and Technology, 40, 155-162. https://doi.org/10.1016/j.postharvbio.2005.12.014

FAO. (1994). Neglected crops 1492 from a different perspective. In J. E. Hernández Bermejo, \& J. León, (Eds). Etnobotánica 92 Programme: Botanical Garden of Cordoba. P. 63-74. Retrieved from http://www.fao.org/docrep/018/t0646e/t0646e.pdf

Fertonani, H. C. R., Scabio, A., Canteri-Schemin, M. H., Carneiro, E. B. B., Nogueira, A., \& Wosiacki, G. (2006). Influence of acid concentration on extraction and quality of apple pomace pectin. Semina: Ciências Agrárias, 27, 599-612. http://dx.doi.org/10.5433/1679-0359.2006v27n4p599

Goulao, L. F., \& Oliveira, C. M. (2008). Review-Cell wall modifications during fruit ripening: when a fruit is not the fruit. Trends in Food Science and Technology, 19, 4-25. https://doi.org/10.1016/j.tifs.2007.07.002

Goulao, L. F., Almeida, D. P., \& Oliveira, C. M. (2010). Effect of enzymatic reactions on texture of fruits and vegetables. In A. Bayindirli (Ed). Enzymes in fruit and vegetable processing: chemistry and engineering applications, (pp.71-122). CRC Press: Boca Raton, London. https://doi.org/10.1201/9781420094343-c4

Gross, K. C. (1982). A rapid and sensitive spectrophotometric method for assaying polygalacturonase using 2-cyanoacetamide. Horticultural Science, 17, 933-944.

Gross, K. C., \& Wallner, S. J. (1979). Degradation of cell wall polysaccharides during tomato fruit ripening. Plant Physiology, 63, 117-120. https://doi.org/10.1104/pp.63.1.117

Li, X., Zhao, W., Zhou, X., Feng, J., Gao, Y., Yao, X., .... Zhao, F. (2017). The use of toluidine blue staining combined with Paraffin sectioning and the optimization of freeze-thaw counting methods for analyzing root-knot nematodes in tomato. Horticulture, Environment, and Biotechnology, 58, 620-626. https://doi.org/10.1007/s13580-017-0042-3

Jariene, E., Danilčenko, H., Vaitkevičienè, N., \& Nataliia, C. (2015). Quality changes in great pumpkins and coloured potatoes during storage. Acta Scientiarum Polonorum, 14, 121-132.

Kader, A. A., \& Barret. M. D. (2004). Classification, composition of fruits and postharvest maintenance of quality. In M. D. Barret, L. Somogyi, \& H. Ramaswamy (Eds). Processing fruits, Science and Technology, $2^{\text {nd }} e d$ (pp. 3-20). CRC Press: Weimar Texas. https://doi.org/10.1201/9781420040074.pt1

Megazyme International. (2014). Sucrose, D-fructose and D-glucose assay procedure (pp.1-12). Megazyme International: Ireland.

Megazyme International. (2016). Total starch assay procedure (pp.1-15). Megazyme International: Ireland.

Mollendorf, V., Villiers, L. J., Jacobs, O. T., \& Westraad, I. G. (1993). Molecular characteristics of pectic constituents in relation to firmness, extractable juice, and wooliness in nectarines. Journal of the American Society for Horticultural Science, 118, 77-80. https://doi.org/10.21273/JASHS.118.1.77

NCBE. (2000). Enzymes in fruit juice production-In a jam and out of juice, version 1.0. Retrieved from www.ncbe.reading.ac.uk

FAO, 2019. FAOSTAT-pumpkins, squash \& gourds glossaries: UN Statistics Division. Retrieved from http://data.un.org/Data.aspx?d=FAO\&f 
Nicholass, F. J., Smith, C. S., Schuch, W., Bird, C. R., \& Grierson, D. (1995). High-levels of ripening-specific reporter gene-expression directed by tomato fruit polygalacturonase gene-flanking regions. Plant Molecular Biology, 28, 423-435. https://doi.org/10.1007/BF00020391

Ng, J. K., Schröder. R., Sutherland, P. W., Hallett, I. C., Hall, M. I., ... Prakash, R. (2013). Cell wall structures leading to cultivar differences in softening rates develop early during apple (Malus $x$ domestica) fruit growth. BMC Plant Biology, 13, 1-16. https://doi.org/10.1186/1471-2229-13-183

Rahman, M. A., Miaruddin, M., Khan, M. H. H., Masud, M. A. T., \& Begum, M. M. (2013). Effect of storage periods on postharvest quality of pumpkin. Bangladesh Journal of Agricultural Research, 38, 247-255. https://doi.org/10.3329/bjar.v38i2.15888

Sharma, S., \& Rao, R. T. V. (2013). Nutritional quality characteristics of pumpkin fruit as revealed by its biochemical analysis. International Food Research Journal, 20, 2309-2316.

Stitt, M., \& Sonnewald, V. (1995). Regulation of metabolism in transgenic plants. Annual Review of Plant Physiology, 46, 341-68. https://doi.org/10.1146/annurev.pp.46.060195.002013

Van Soest, P. J., \& Robertson, J. B. (1990). Analysis of forage and fibrous food in a laboratory manual for animal science 613, New York: Cornell University, Ithaca.

Wills, R. B. H., Lim, J. S. K., \& Greenfield, H. (1984). Changes in chemical composition of "Cavendish" banana (Musa acuminata) during ripening. Food Biochemistry, 8, 69-77.

https://doi.org/10.1111/j.1745-4514.1984.tb00315.x

\section{Copyrights}

Copyright for this article is retained by the author(s), with first publication rights granted to the journal.

This is an open-access article distributed under the terms and conditions of the Creative Commons Attribution license (http://creativecommons.org/licenses/by/4.0/). 